\title{
Chronic rhinitis in glassblowers
}

\author{
Nenad Baletic ${ }^{1 *}$, Aleksandar Peric ${ }^{2}$ \\ From 9th Symposium of Experimental Rhinology and Immunology of the Nose (SERIN 2013) \\ Leuven, Belgium. 21-23 March 2013
}

\section{Introduction}

At their workplace glassblowers are exposed to intensive infrared radiation, high temperature and low humidity of the air, hot gases, evaporations and dust particles, while the glassblower's pipe are the most important forms of exposure to noxious agents.

\section{The aim}

1. To examine the prevalence of chronic rhinitis among glassblowers (experimental group) and control group based on objective findings at nasal mucosa. 2. To examine using appropriate statistical methods whether or not chronic rhinitis have higher prevalence in group of glassblowers. 3. To examine whether or not prevalence of chronic rhinitis depends on duration of exposure to noxious factors.

\section{Material and methods}

Only noninfective chronic inflammation of nasal mucosa was considered in the present study. Infective, allergic, autonomic, eosinophylic, hormonal, autoimmune rhinitis, rhinitis "medicamentosa", as well as septal deviations or other anatomical deformities were excluded using appropriate standard diagnostic methods. For assessment of difference of chronic rhinitis prevalence in experimental and control group, we used chi-square test.

\section{Results}

For comparison of chronic rhinitis prevalence in experimental and control group using chi-square test we got result: $\mathrm{CHI}=27.449, \mathrm{DF}=2, \mathrm{P}=1.614 \times 10-7<0.05$; there was highly significant statistical difference between chronic rhinitis prevalence in experimental and control group. Remarkable graph of distribution of chronic rhinitis among glassblowers and control group was obtained in this study.

${ }^{1}$ Military Medical Academy, Belgrade, Serbia

Full list of author information is available at the end of the article

\section{Conclusion}

Glassblowers have higher prevalence of chronic rhinitis than control group. Both factors, duration of exposure and membership of glassblowers cohort are important factors for chronic rhinitis, but membership of glassblowers cohort si more important factor.

\section{Author details}

${ }^{1}$ Military Medical Academy, Belgrade, Serbia. ${ }^{2}$ Military Medical Academy, ENT, Belgrade, Serbia.

Published: 16 July 2013

\section{doi:10.1186/2045-7022-3-S2-P10}

Cite this article as: Baletic and Peric: Chronic rhinitis in glassblowers.

Clinical and Translational Allergy 2013 3(Suppl 2):P10.
Submit your next manuscript to BioMed Central and take full advantage of:

- Convenient online submission

- Thorough peer review

- No space constraints or color figure charges

- Immediate publication on acceptance

- Inclusion in PubMed, CAS, Scopus and Google Scholar

- Research which is freely available for redistribution
() Biomed Central
C Biomed Central

(c) 2013 Baletic and Peric; licensee BioMed Central Ltd. This is an Open Access article distributed under the terms of the Creative Commons Attribution License (http://creativecommons.org/licenses/by/2.0), which permits unrestricted use, distribution, and reproduction in any medium, provided the original work is properly cited. 